\title{
An endoscopic cadaveric study: Accessory maxillary ostia
}

\author{
Endoskopik kadavra çalışması: Aksesuar maksiller ostium
}

\author{
Alper Sindel' ${ }^{1}$, Murat Turhan², Eren Ogut ${ }^{3}$, Mehmet Akdag², Aslı Bostancı², Muzaffer Sindel ${ }^{3}$
}

\begin{abstract}
Objective: Endoscopy is now being used for diagnosis and surgical treatment of disorders of the nose and paranasal sinuses. Direct observations of mucociliary clearance patterns have shown that there are clear cut pathways in the sinuses, with secretions always trying to leave through the natural ostia.' Maxillar ostia is exists behind the upper part of the medial wall and often at intersection region of the rear lower infindubulum and lower front surface of the ethmoid bulla. Accessory ostium exists at the $25-30 \%$ of the general population instead of the natural ostium. There are some features that differentiate the accessory ostium and natural ostium.
\end{abstract}

Methods: To determine the incidence and location of the accessory ostium 29 fromaldehyde fixed adult cadaver was examined with endoscope.

Results: The accessory ostium is encountered at 8 cases $(13.8 \%)$. These are located at rare-middle, front-middle and rear in $2(0.03 \%), 3(0.05 \%), 3(0.05 \%)$ cases respectively. Recognition of the maxillary ostia is tedious while performing endoscopic procedures which accounts for a high rate of orbital complications for a novice performing surgery in this region.

Conclusion: It is therefore imperative to know the landmarks in this regions which may be obliterated by disease. Radiologist should be aware of this entity as it can appear as communication between the maxillary sinus and nasal cavity on sinus imaging examinations.

Key words: Accessory maxillary ostia, endoscopic study, cadaveric study

\section{INTRODUCTION}

The morphological and radiological evaluations of paranasal sinuses and nasal cavity, combined with

\section{ÖZET}

Amaç: Endoskopi burun ve paranazal sinüs hastalıklarının teşhisi ve cerrahi tedavisi için kullanılmaktadır. Direkt gözlem; sekresyonun mukosiliyer açıklıktan her zaman doğal ostium'a doğru olduğunu göstermiştir. Maksiller sinüs ostiumu medial duvarın arka üst bölümünde, sıklıkla da infindibulum alt arka yarısı ile etmoid bullanın ön alt yüzeyinin kesişme bölgesindedir. Gerçek ostium dışında genel popülasyonun \%25-30 kadarında aksesuar ostiuma rastlanır.

Yöntemler: Aksesuar ostium'un lokasyonunu ve insidansını saptamak için formaldehitle fikse edilmiş 29 erişkin kadavrası endoskopla incelendi.

Bulgular: Aksesuar ostium 8 vakada görüldü (13,8\%). Bunların lokalizasyonu sırasıyla ortaya yakın, ön-orta ve arka $[2(0,03 \%), 3(0,05 \%), 3(0,05 \%)]$ olarak bulundu.

Sonuç: Endoskopik işlemleri uygularken maksiller ostium'u tanımlamak bu bölgedeki cerrahi uygulamalardaki orbital komplikasyonlar için yüksek bir önem taşır. Hastalık nedeni ile oblitere olabileceği için bu bölgedeki belirli noktaları bilmek şarttır. Sinüs görüntülenme yöntemlerinde maksiller sinüsle burun boşluğu arasında iletişim varmış gibi görünebilir bu nedenle radyolog aksesuar maksiller ostium'un olabileceğinin farkında olmalıdır.

Anahtar kelimeler: Aksesuar maksiller ostium, endoskopik çalışma, kadavra çalışması

endoscopic examination, provide detailed information on the anatomy and pathology of the region [1] Endoscopic sinus surgery presents a series of com-

\footnotetext{
${ }^{I}$ Akdeniz Üniversitesi Diş Hekimliği Fakültesi Ă̆ız, Diş ve Çene Cerrahisi Anabilim Dalı, Antalya, Türkiye

${ }^{2}$ Akdeniz Üniversitesi Tıp Fakültesi Kulak Burun Boğaz Hastalıkları Anabilim Dalı, Antalya, Türkiye ${ }^{3}$ Akdeniz Üniversitesi Tip Fakültesi Anatomi Anabilim Dalı, Antalya

Yazışma Adresi /Correspondence: Alper Sindel, Akdeniz Üniversitesi Diş Hekimliği Fakültesi Ağız, Diş ve Çene Cerrahisi Anabilim Dalı Antalya Email: sindelm@akdeniz.edu.tr Geliş Tarihi / Received: 24.10.2013, Kabul Tarihi / Accepted: 23.11.2013 Copyright (C) Dicle Tıp Dergisi 2014, Her hakkı saklıdır / All rights reserved
} 
plications that can vary depending on the technique used and the surgeon's experience [2]. This information as well as the inflammatory cells, which causing to the sinusitis is leading the way endoscopic surgery in the treatment. Currently, the frequent utilization of the functional endoscopic sinus surgery technique significantly reduces morbidity in patients [3]. The use of this technique has attached great importance to morphological and radiological studies on the anatomy of the paranasal region [4]. Knowledge of normal anatomy is crucial for accurate diagnosis of sinonasal pathology. In addition, the most frequent anatomical variants should be identified to reduce surgical risks [5].

Maxillary hiatus is closed with the descending part of the lacrimal bone and uncinate process of ethmoid bone above, maxillary process of inferior nasal concha below, and perpendicular plate of palatine bone behind. Maxillary hiatus is located in the third section of posteroinferior infundibulum in $71.8 \%$ cases [6]. The anterior fontanelle includes the ostium, which is located in the medial maxillary sinus, and the posterior fontenelle is closed by a mucus membrane and periosteum. The average size of the maxillary hiatus is 2.4 millimeters. Duplication is rarely seen in the maxillary hiatus. The maxillary accessory hiatus is one of the anatomical variations that may play a role in the development of chronic maxillary sinusitis. Although some authors claim that accessory ostia develop following acute maxillary sinusitis, it is not clear whether they are congenital or acquired [7]. Accessory maxillary ostium, often encountered in the posterior fontanelle of the lateral nasal wall, should not be confused with maxillary hiatus. Accessory maxillary sinus ostia are found in approximately $30 \%$ of patients with chronic rhinosinusitis (CRS) and in $10-20 \%$ of healthy subjects $[8,9]$. This additional ostium may cause mucus to recirculate from the sinus to the nasal cavity through the natural ostium and back to the sinus through accessory ostium. Accessory maxillary ostium can be found in varying numbers. The prevalence of the accessory maxillary ostium in humans has been reported to be between $0-43 \%$ in various cadaveric and patient studies [10-13]. In sizes ranging from $1 \mathrm{~mm}$ to $10 \mathrm{~mm}$ [14].

The maxillary sinuses, the largest of the human paranasal sinuses, are particularly susceptible to infection, as excess fluid cannot easily drain from them by gravity. Direct observations of mucociliary clearance patterns have shown that there are clearcut pathways in the sinuses, with secretions always trying to leave through the natural ostia. The ostium of the maxillary sinus is on the highest part of the medial wall of the sinus and is therefore poorly placed from the point of view of free drainage; in addition, it does not open directly into the nasal cavity, but into the narrow ethmoidal infundibulum, inflammation of which can further interfere with drainage [15]. Genc at al have investigated the development of maxillary accessory ostia, and shown for the first time that accessory maxillary ostia developed following experimental sinusitis in rabbits. [16]. There are non-functional ostia that serve to drain the sinus, only if the natural ostium is blocked and intrasinus pressure moves material out of the ostium. These accessory ostia exist in $25-30 \%$ of the general population, instead of the natural ostium. The accessory ostium is located $5-10 \mathrm{~mm}$ superior to the attachment point of the inferior concha, and opens to the lateral nasal wall, or less frequently, to the infindubulum. While performing endoscopic sinus surgery, it is important to differentiate natural ostium from accessory ostium.

\section{METHODS}

Twenty-nine formaldehyde-fixed adult cadavers were examined using an endoscope to determine the incidence and location of the accessory ostium. Nasal cavities of each cadaver were examined with a 4.0-mm, 0- and 30-degree rigid Karl Storz Hopkins endoscope. First, the endoscope was positioned at the base of the nose, and the anatomical structures, such as the septum, inferior meatus, inferior nasal concha, middle nasal concha, nasopharynx and the anterior face of sphenoidal sinus were viewed. Than middle nasal concha medialized, after following middle nasal meatus, uncinate process were evaluated with natural maxillary sinus ostium and accessory ostium. A total of 29 cadavers ( 21 male, 8 female) were used in this study.

\section{RESULTS}

In this study, the natural ostia in all the cadavers were located using an endoscope, and 15 cases 
$(51.7 \%)$ of them were encountered in the posterior third of the semilunar hiatus. In addition, septal deviations were determined in 10 cases $(34.4 \%)$ of the cadavers on the right side. Maxillary ostia were found behind the upper part of the medial wall, and at intersection of the rear lower infundibulum and lower front surface of the ethmoid bulla. The accessory ostia were encountered in 8 cases $(13.8 \%)$. These were located in the rear-middle, front-middle and rear in $2(0.03 \%), 3(0.05 \%)$, and $3(0.05 \%)$ cases, respectively (Figure 1).

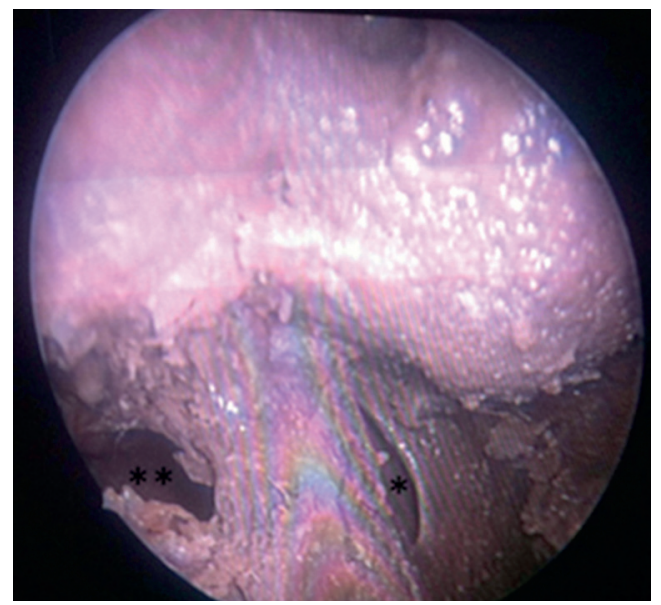

Figure 1. Endoscopic micrograph showing the accessory and natural maxillary ostia. *: accessory ostium: natural ostium

\section{DISCUSSION}

The use of endoscopes on the paranasal sinuses during surgery improves visualization, enables greater preservation of normal structures, and reduces the necessity for wide exposure. A considerable time investment is therefore necessary in order to learn to identify the potential significance of the wide anatomic variations.

Endoscopic sinus surgery, which is the commonly performed nasal surgery, has its own problems if not performed properly. Success of maxillary sinus antrostomy depends on including the natural ostium to the antrostomy. For this to happen, the natural ostium should be identified during the surgical procedure [16]. Natural ostium is present anteriorly, not visible under routine direct nasal endoscopic examination, oval in shape, and oriented transversely. The maxillary sinus typically opens into the inferior aspect of the ethmoidal infundibulum through an ostium that lies recessed in the superomedial aspect of the sinus. The mucus drained through the natural ostium may re-enter the maxillary sinus through the accessory ostium [15] . The active mucociliary transport of the maxillary sinus is towards the natural ostium and the accessory ostia do not take part in the physiological drainage of the maxillary sinus even if the natural ostium is blocked [17].

The maxillary sinus typically drains through a canal that is formed in part by a portion of the anterior ethmoid bone and may be up to $22 \mathrm{~mm}$ in length [18]. According to Matthews et al.the size of the maxillary sinus ostium averages $2-4 \mathrm{~mm}$, and it can vary from 1- $17 \mathrm{~mm}$ [15].

In approximately $15 \%$ of patients, accessory maxillary ostia are present, opening directly into the middle meatus. However, these ostia typically do not receive active mucociliary clearance from the sinus. The incidence of accessory ostia appears to be higher in patients who have infundibular obstruction or a history of maxillary sinus disease, suggesting that they may occur as a result of a pathologic condition and then remain patent. Rarely, the natural ostium itself may open directly into the middle meatus, posterior to the free border of the uncinate process $[19,20]$.

According to a study by Balasubramanian, the accessory ostium is present posteriorly, oriented anteroposteriorly, spherical in shape, and can be easily visualized during routine nasal endoscopic examination [16]. Anatomic variations including maxillary accessory ostium have been implicated in the pathogenesis of chronic maxillary sinus infection. Maxillary accessory ostium disturbs mucociliary clearance of maxillary sinus due to the recycling of mucus between the natural and accessory ostia. This process may result in chronic maxillary sinusitis [15], and potentially cause of persistent sinusitis [21]. Maxillary sinus ostium size averages $2-4 \mathrm{~mm}$ and it can vary from $1-17 \mathrm{~mm}$.

A possible mechanism of formation of accessory ostia is obstruction of the primary ostium by maxillary sinusitis or due to anatomic and pathologic factors in the middle meatus resulting in the rupture of membranous areas known as fontanelle 
[12]. The incidence of accessory maxillary ostium (AMO) has been recorded to range from $0-43 \%$. In the present study, accessory maxillary ostia were found within the membranous fontanelle of the lateral nasal wall in $9(22.5 \%)$ specimens. Similar observations were earlier noted by Myerson [22]. In $30.7 \%$, Schaffer [23]. in 41\%, and Van Alyea [24]. in $23 \%$ of specimens. Though most authors have not specified the location of the AMO with reference to the fontanelle, Stammberger [17] and Kennedy [19] reported their presence either in the anterior nasal fontanelle (ANF) or posterior nasal fontanelle (PNF). May et al. [11], however, found their presence restricted to the PNF posteroinferior to natural ostia. Van Alyea [24] published his observations from the anatomic study of the surgical accessibility of the ostium maxillare in 163 specimens. He found that the natural ostia were easily accessible in $40 \%$ of specimens, but that in $20 \%$, the ostia could not be cannulated because of the anatomic configuration of the uncinate process or the bulla, or the size of the ostia. In the remainder of the specimens, cannulation was only possible because of the skull, experience of the surgeon, or because an accessory ostium was present [24]. May et al. [11] investigated the location of the maxillary ostium and its importance to the endoscopic sinus surgeon in their study. Accessory ostia of the maxillary sinus are found in approximately $30 \%$ of skulls; as many as three in one skull have been reported. Normally, the medial wall of the orbit is in the same vertical plane as the maxillary ostium [11].

Maxillary ostia are located behind the upper part of the medial wall, and often at the intersecting region of the rear lower infundibulum and lower front surface of the ethmoid bulla. It has a diameter of 3-4 $\mathrm{mm}$ in average, and $5 \mathrm{~mm}$ of diameter in two areas. According to Porter [25], the natural maxillary ostium is located at the superior aspect of the medial wall of the sinus. Intranasally, it is usually in the posterior half of the ethmoid infundibulum, or behind the lower $1 / 3$ of the uncinate process. The posterior edge of the ostia is continuous with the lamina papyracea, thus a reliable landmark for the lateral limit of surgical dissection. The average size of the ostium is $2-4 \mathrm{~mm}$, but it can vary from 1 $-17 \mathrm{~mm}$. The ostium is much smaller than that actual bony defect, as mucosa fills this area and defines the extent of the opening. $88 \%$ of maxillary ostia are hidden behind the uncinate process and therefore cannot be visualized endoscopically. In some individuals, the anterior or posterior fontanelles may be patent, which results in an accessory ostium. They are non-functional ostia that serve to drain the sinus only if the natural ostium is blocked and intrasinus pressure/gravity moves material out of the ostium. Accessory ostia are usually found in the posterior fontanelle [25].

Accessory ostia into the maxillary sinus have been reported in between 25 and $50 \%$ of patients. The ostium may vary from pinpoint in size to several millimeters. The accessory ostia are found in the mid-portion of the lateral nasal wall at the sites of the anterior or posterior fontanelles [17].

Accessory ostium occurs in $25-30 \%$ of the general population instead of the natural ostium. The accessory ostium is located $5-10 \mathrm{~mm}$ superior to the attachment point of the inferior concha, and it opens to the lateral nasal wall, or less frequently, to the infundibulum [26]. Ethmoid infundibulum separated into four parts as front, front-middle, front-rear, and rear, and the occurrences of the ostium at these locations are $5.5 \%, 11 \%, 71.8 \%$, and $11.6 \%$, respectively [24] The ostium is located at the rear part in more than $80 \%$ of the cases. The accessory ostium may occur either congenitally or secondary to disease. They are usually located at the membranous fontanelle between the mucosal sinus and nasal mucosa. There are some features that differentiate the accessory ostium and natural ostium. The natural foramen is oval, located more anteriorly than the accessory ostium, and has an angle to the vertical plane. The accessory ostium, located posterior, may be seen during direct nasal examination. It is round, and parallel to the vertical plane. There are two fontanelles (anterior, posterior) related to the free edge of the uncinate processes. In $20-25 \%$ of normal population, the accessory ostium is encountered in the posterior fontanelle [27]. Myerson [22] has investigated 114 lateral nasal walls of adult heads in their fresh state. The position, size, shape and relations of the maxillary ostium were noted. Special attention was paid to its accessibility for sounding and for irrigation. The presence of accessory ostia was sought for and noted. The prevalence of the accessory maxillary ostium in humans has 
been reported to be between \%0-43 in various cadaveric and patient studies $[10,12,28]$. Thirty halfheads from fifteen adult Indian cadavers were dissected to study the incidence, location and side of secondary maxillary ostia by Kuma RH et al. [12] In their studies, AMO were present in $9(30 \%)$ halfheads, located in the ANF in 6 (66.7\%), in the PNF in $2(22.2 \%)$, and at the hiatus semilunaris (HS) in $1(11.1 \%)$. It was twice as frequently present on the right side compared to the left. $5(55.6 \%)$ sides had single, whereas 4 (44.4\%) had twin AMO. Two twins AMO were seen in the ANF, and one each in PNF and HS. 7 of these were found unilaterally, and 2 were present bilaterally. All were present in the male cadavers, except for a single AMO in the female half-head.

Chung et al report a case of one asymptomatic 28-year-old male with mucus circulation between the natural ostium and the accessory ostium of the maxillary sinus. In the right middle meatus, an endoscopic examination showed mucopurulent discharge coming into the maxillary sinus through an accessory opening [29].

Prasanna et al in their study, accessory maxillary ostia were found within the membranous fontanelle of the lateral nasal wall in $9(22.5 \%)$ specimens and maxillary sinus ostium opened more commonly into posterior third of the HS. AMO was another variation seen in nearly three-fourths of the cases which opened into membranous meatus inferior to the uncinate process [30].

In this study, the localization of the natural ostium was studied using endoscopy in cadavers, and natural ostia were encountered at a ratio of $51.7 \%$ in the posterior $1 / 3$ of HS. In addition, septal deviations were determined at a ratio of $\% 34.4$, located more on the right side. Moreover, in this study, accessory ostia were identified in $8(8.6 \%)$ cases. These were located at the rare-middle, front-middle and rear in $2(0.03 \%), 3(0.05 \%)$, and $3(0.05 \%)$ of all cases, respectively. Our findings were in line with current literature.

With the advent of functional endoscopic sinus surgery (FESS) and coronal computed tomography imaging, considerable attention has been directed toward paranasal region anatomy. Detailed knowledge of anatomic variations in paranasal sinus region is critical for surgeons performing FESS, as well as for the radiologist involved in the preoperative work-up. Anatomical variants with certain accompanying pathologies directly influence the success of diagnostic and therapeutic management of paranasal sinus diseases. It is suggested that remarkable anatomic variations of paranasal sinus and their pathologic consequences should be well-defined in order to improve the success rate of management strategies. In order to avoid potential complications of sinus surgery, the radiologist must pay close attention to anatomical variations in preoperative evaluations.

Recognition of the maxillary ostia is tedious while performing endoscopic procedures, which accounts for a high rate of orbital complications for a novice performing surgery in this region. It is therefore imperative to know the landmarks in this region, which may be obliterated by disease. Radiologists should be aware of this entity, as it can appear as communication between the maxillary sinus and nasal cavity in sinus imaging examinations.

\section{REFERENCES}

1. Anon JB. Klimek L. Mosges R, Z. S. Computer-assisted endoscopic sinus surgery: an international review. Otol Clin North Am 1997;30:389-401.

2. Celis L, Melcón M, Calvo F, et al. Complications of endoscopic sinus surgery in a residency training program . Acta Otorrinolaringol Esp 2010; 61: 345-350.

3. Zinreich SJ., K. D., Rosenbaum AE., Gayler BW., et al. Paranasal sinuses: CT Imaging requirements for endoscopic surgery. Radiology 1987;163:769-775.

4. Aydınlıoğlu A, D. S., Şakul BU, Keleș P, et al. Burun dış duvarı anatomisinin Endoskobik Sinüs Cerrahisi Açısından İncelenmesi. Türkiye Klinikleri Diş Hekimliği Bilimleri Dergisi. 1996;20:89-93.

5. Champsaur P, Pascal T, Vidal V, et al. Radioanatomy of the paranasal sinuses. J Radiol 2003;84:885-900

6. Tür A. [Sinüs Hastalıkları Özkarakaş H, Yıldırım N. İstanbul; Nobel Tip Kitabevleri; 2003;8:57-68.

7. Genc S., O. M., Titiz A, Unal A . Development of maxillary accessory ostium following sinusitis in rabbits. Rhinology 2008;46:121-124.

8. Joe JK, HoSY, Yanagisawa E. Documentation of variations in sinonasal anatomy by intraoperative nasal endoscopy . Laryngoscope 2000;110:229-235.

9. Jones NS. CT of the paranasal sinuses: A review of the correlation with clinical, surgical and histopathological findings. Clin Otolaryngol Allied Sci 2002; 27:11-17. 
10. Lang J. Clinical anatomy of the nose, nasal cavity and paranasal sinuses. New York, Thieme Medical Publishers Inc. 1989;25:57-69.

11. May MS, Korzec K. The location of the maxillary os and its importance to the endoscopic sinus surgeon. Laryngoscope 1990; 100:1037-1042.

12. Kuma RH, Kaka RS. Accessory Maxillary Ostia: Topography and Clinical Application. J Anat Soc India. 2001;50:35.

13. Jog M, M. GW. How frequent are accessory sinus ostia? J Laryngol Otol. 2003;117:270-272.

14. Youngs R., E. K., Watson M. Paranasal Sinuses A Handbook of Applied Surgical Anatomy 2006;135:339

15. Matthews BL, Burke AJ. Recirculation of mucus via accessory ostia causing chronic maxillary sinus disease. Otolaryngol Head Neck Surg 1997;117:422-423.

16. Balasubramanian T. Advanced anatomy of lateral nasal wall: For the endoscopic sinus surgeon. Otolaryngol Online J Rhinol 2012;2:4-9.

17. Stammberger H. Functional Endoscopic Sinus Surgery. The Messerklinger technique. Philadelphia, B.C. Decker, 1990;247:63-76.

18. Wilkerson WW. Antral window in the middle meatus. Arch Ophthalmol 1949;49:463-489 .

19. Kennedy DW. The functional endoscopic approach to inflammatory sinus disease: currentperspectives and technique modifications. Am J Rhinol 1988;2:89-96.

20. Zinreich SJ. Paranasal sinüs imaging. Otolaryngol Head Neck Surg 1990;103:863-869.
21. Kane KJ. Recirculation of mucus as a cause of persistent sinusiti . Am J Rhinol 1997;11:361-369.

22. Myerson MC. The natural orifice of the maxillary sinus: I . Anatomic Studies Arch Otolaryngol Head Neck Surg 1932;15:80-91.

23. Schaeffer JP. The lateral wall of the cavum nasi in man, with especial reference to the various developmental stages. J Morphology 1910;21:613-707.

24. Van Alyea OE. Ostium maksillare: anatomic study of its surgical accessibility. Arch Otolaryng Head and Neck Surg. 1936;24:552-569.

25. Porter GT, Quinn FB. Paranasal Sinuses: Anatomy and Function. The University of Texas Medical Branch (UTMB), Department of Otolaryngology, Galveston TX January Grand Rounds presentation. 2002;1:1-3.

26. Salman SD. Complications of endoscopic sinus surgery. Am J Otolaryngol 1991;12:326-328.

27. Van Alyea OE. Management of chronic sinus disease. Ann Otol Rhinol \& Laryngol 1945;54:443-457 .

28. Earwaker J. Anatomic variants in sinonasal CT. RadioGraphics 1993;13:381-415.

29. Chung SK, Na DG. Mucus circulation between accessory ostium and natural ostium of maxillary sinus. J Laryngol \& Otology 1999;113:865-867.

30. Prasanna LC. The location of maxillary sinus ostium and its clinical application. Indian J Otolaryngol Head Neck Surg 2010;62:335-337. 